\title{
Persepsi Masyarakat Desa Bomo Blimbingsari Banyuwangi Tentang Kinerja Pemerintahan Desa Dalam Memberikan Pelayanan Kepada Masyarakat
}

\author{
Harjianto $^{1 *}$, Sri Sedar Mahaeni ${ }^{2}$, Leni Widiyanti ${ }^{3}$ \\ 1,2,3 Universitas PGRI Banyuwangi \\ "Correspondence email: hr.bwin@gmail.com ${ }^{1 *}$; sridedar1956@gmail.com²; leniwidiyanti97@gmail.com³
}

\begin{abstract}
Abstrak. Sistem penyelenggaran pemerintahan desa berfungsi sebagai pengayom, pembina, penggerak dan pelayanan. Masyarakat desa memerlukan pelayanan untuk memenuhi kebutuhan yang tidak dapat di penuhi sendiri. Penelitian ini bertujuan untuk mengetahui persepsi masyarakat terhadap kinerja pemerintahan desa Bomo Blimbingsari Banyuwangi dalam memberikan pelayanan kepada warga masyarakat. Jenis penelitian ini adalah deskriptif kualitatif dengan pendekatan fenomologis. Subjek dalam penelitian ini terdiri dari pemerintahan desa dan warga masyarakat desa Bomo. Pengumpulan data dilakukan dengan teknik observasi, teknik wawancara, dan teknik dokumentasi. Teknik analisis data yang digunakan adalah teknik analisis interaktif yang meliputi pengumpulan data, reduksi data, penyajian data, kemudian menarik suatu kesimpulan. Hasil penelitian ini menunjukkan bawah persepsi masyarakat terhadap kinerja pemerintahan desa Bomo kecamatan Blimbingsari Banyuwangi dalam memberikan pelayanan kepada warga masyarakat 76 persen menganggap cukup baik dan memuaskan. Hal ini dibuktikan dengan pelayanan yang ramah, cepat, dan tepat waktu, sedangkan 24 persen menganggap kurang memuaskan dikarenakan mereka harus bolak-balik dalam melengkapi berkas. Adapun jenis layanan yang diberikan yaitu 1) Surat Keterangan Kematian; 2) Surat Pengantar SKCK; 3) Surat Keterangan Kelahiran; 4) Surat Keterangan Tidak Mampu (SKTM); 5) Surat Pengantar Kartu Keluarga; 6) Surat Keterangan Penganti Nama; 7) Surat Keterangan Pemasangan Listrik, Mampu Masyarakat Yang Kurang Mampu; 8) Surat Keterangan Pindah Alamat Rumah dan Surat Keterangan Datang; 9) Surat Keterangan Untuk Nikah (SKUN); 10) Surat Mendirikan Banggunan; 11) Surat Pengantar KTP.
\end{abstract}

Kata Kunci: Persepsi Masyarakat; Kinerja; Pelayanan

\begin{abstract}
The village administration system functions as a guard, guide, mobilizer and service. Village communities need services to meet needs that cannot be fulfilled by themselves. This study aims to determine public perceptions of the performance of the village government of Bomo Blimbingsari Banyuwangi in providing services to community members. This type of research is a qualitative descriptive with a phenomological approach. The subjects in this study consisted of the village administration and members of the Bomo village community. Data collection is done by observation techniques, interview techniques, and documentation techniques. Data analysis technique used is interactive analysis techniques including data collection, data reduction, data presentation, then drawing conclusions. The results of this study indicate that community perceptions of the performance of the village government of Bomo, Blimbingsari Banyuwangi sub-district in providing services to residents 76 percent of people consider that it is good enough and satisfying. This is evidenced by friendly, fast, and timely services, while 24 percent consider it less satisfactory because they must go back and forth in completing the file. The types of services provided are 1) Death Certificate; 2) SKCK Cover Letter; 3) Birth Certificate; 4) Certificate of Disability (SKTM); 5) Family Card Cover Letter; 6) Certificate of Change of Name; 7) Electricity Installation Certificate, Capable of Disadvantaged Communities; 8) Certificate of Moving House Address and Coming Certificate; 9) Certificate of Marriage (SKUN); 10) Letter of Establishment; 11) KTP Cover Letter
\end{abstract}

Keywords: Community Perception; Performance; Service

\section{PENDAHULUAN}

Pemerintahan desa adalah penyelenggaran urusan pemerintahan dan kepentingan masyarakat setempat dalam sistem pemerintahan Negara Kesatuan Republik Indonesia (UU NO.6 2014 pasal 1 ayat 2). Pemerintahan desa merupakan sub sistem dari sistem penyelenggaran pemerintahan nasional yang langsung berada di bawah pemerintahan kabupaten. Aspek terpenting dalam penyelenggaran pemerintahan desa adalah kedudukan kepala desa sebagai pemimpin dan dibantu oleh perangkat desa pada saat melaksanakan tugas, kewajiban dan fungsinya (Solekhan, 2014).
Pemerintahan desa dipimpin oleh seorang kepala desa dan di bantu oleh perangkat desa yang dalam menjalankan tugasnya terdapat pembatasan wewenang. Perangkat desa terdiri dari sekretaris desa dan perangkat desa lainya, disesuaikan dengan kebutuhan dan kondisi budaya masing-masing desa. Pemerintah desa mempunyai tugas membina kehidupan masyarakat, pembinan perekonomian, memelihara kesejahteraan, ketentraman, dan ketertiban masyarakat.

Sistem penyelenggaran pemerintahan desa berfungsi sebagai pengayom, pembina, pelayanan, dan pengerak partisipasi masyarakat. Kehidupan masyarakat desa baik secara kelompok maupun individu 
memerlukan pelayanan untuk memenuhi kebutuhan yang tidak dapat di penuhi sendiri, seperti pelayanan dalam hal kesehatan, pendidikan, pekerjaan, pernikahan, warisan, kelahiran dan perizinan. Penyelenggaraan pemerintahan desa harus bersadarkan pada asas, kepastian, tertib penyelenggaraan pemerintahan, tertib kepetingan umum, keterbukaan proposioanlitas, akuntabilitas, efesiensi, kearifan lokal, keberagaman dan partisipatif (UU No. 6 tahun 2014 pasal 24). Masyarakat setiap waktu selalu menutut pelayanan yang berkualitas dari pemerintah.

Dalam lingkungan pemerintah desa, kepala desa dan seluruh perangkat desa sebagai pelaksana tugas masih banyak jumpai keluhan dari warga masyarakat. Keluhan tersebut didapat dari warga masyarakat desa yang akan mengurus surat-surat keterangan di kantor desa. Di era reformasi ini, masyarakat terbuka dalam memberikan kritikan dan saran kepada pemerintah dalam mengatur dan mengarahkan seluruh kegiatan untuk mencapai tujuan. Pada saat ini pelayanan publik di desa banyak mendapat sorotan dari masyarakat. Dengan adanya keterbukaan informasi dan kebebasan masyarakat menyampaikan pendapat sering ditemukan kritikan terhadap kinerja pelayanan aparat pemerintah desa, baik secara langsung maupun tidak langsung. Hal ini terjadi karana masih rendahnya produktifitas kerja dan disiplin dari aparat pemerintahan desa, serta masih kurangnya sarana kerja yang memadai

Pelayanan secara umum adalah rasa menyenangkan yang diberikan kepada orang lain disertai kemudahan-kemudahan dan memenuhi segala kebutuhanya. Pelayanan adalah suatu bentuk sistem, prosedur atau metode tertentu yang diberikan kepada orang lain agar memenuhi kebutuhannya sesuai dengan harapan (Suwardi, 2011).

Tuntutan masyarakat kepada pemerintah desa untuk melaksanakan penyelenggaraan pemerintah yang baik adalah dengan meningkatnya tingkat pengetahuan dan pendidikan masyarakat, selain adanya pengaruh globalisasi. Oleh karena itu tuntutan merupakan hal yang wajar dan sudah seharusnya direspon oleh pemerintah desa dengan melakukan perubahan yang terarah pada terwujudnya penyelenggaraan pemerintahan yang baik. Oleh karena itu bidang pelayanan umum masih perlu pembenahan sungguh-sungguh dalam berbagai sektor yang menjadi pendukung terhadap pelayanan umum yang baik. Munculnya pelayanan umum disebabkan oleh adanya kepentingan umum di masyarakat. Pelayanan umum itu sendiri bukanlah sasaran suatu kegiatan melainkan suatu proses yang harus dilalui untuk mencapai sasaran tertentu yang telah ditetapkan.

Pelayanan pemerintah desa tergolong dalam jenis pelayanan publik karena adanya kepentingan umum dalam masyarakat yang dilayani di kantor desa. Kepentingan umum yang ada di masyarakat merupakan sasaran utama dalam penyelenggaraan pelayanan publik. Aparat pemerintah sebagai birokrat ditingkat kelurahan dituntut untuk mampu menangani kendala-kendala yang dihadapi dalam usaha-usaha pembangunan yang pemerintah. Aparat pemerintah desa harus mampu melaksanakan tugas dan fungsi utamanya yaitu memberikan pelayanan kepada warga masyarakat dengan baik, cekatan, efektif dan efisien.

UU No. 25 tahun 2009 tentang pelayanan publik menjelaskan bahwa pelayanan publik adalah kegiatan atau rangkaian kegiatan dalam angka pemenuhan kebutuhan pelayanan sesuai dengan peraturan perundang-perundangan bagi setiap warga Negara dan penduduk atas barang, jasa dan atau pelayanan administratif yang disediakan oleh penyelenggara pelayanan publik. Pelayanan umum yang terkait dengan kinerja perangkat desa dalam memberikan pelayanan di masyarakat.

Perkembangan yang ada di desa Bomo sangat maju sekali dibandingakan dulu sebelum tahun 2014 . Seiring dengan kemajuan tersebut pemerintahan desa berusaha untuk memberikan pelayanan yang lebih baik kepada warga masyarakat. Salah satunya memberikan kemudahan kepada warga masyarkat desa dalam membuat surat keterangan dan juga surat menyurat lainnya.

Pelayanan bisa dikatakan dapat memuaskan jika telah memenuhi harapan penerima layanan tersebut. Adapun harapan pelayanan tersebut dapat diukur dengan melihat terpenuhi atau tidaknya pelayanan yang diberikan perangkat desa dengan berdasarkan sepuluh (10) prinsip pelayanan umum yang telah diperjelas dengan Keputusan Menteri Pendayagunaan Aparatur Negara Nomor 63/KEP/M.PAN/7/2003.

Kinerja berasal dari kata "performance", yang mengandung arti daya guna, prestasi atau hasil. Kinerja adalah hasil atau tingkat keberhasilan seseorang secara keseluruhan selama periode tertentu di dalam melaksanakan tugas dibandingkan dengan berbagai kemungkinan, seperti standard hasil kerja, target atau sasaran atau kriteria yang telah ditentukan terlebih dahulu dan telah disepakati bersama (Schermerhorn, Hunt, dan Osborn dalam Ponijan, 2012).

Kinerja atau performance adalah sebagai sesuatu yang harus dicapai, prestasi yang diperlihatkan dan kemauan kerja. Pengertian performance dalam arti luas selalu dipergunakan dengan kata-kata job performance atau work performance yang berarti hasil kerja atau prestasi. Pelayanan kepada masyarakat bisa dikategorikan efektif jika masyarakat mendapatkan kemudahan pelayanan dengan prosedur yang singkat, cepat, tepat, dan memuaskan. Pemerintah dituntut untuk dapat memberikan pelayanan kepada public masyarakat dengan sebaik-baiknya dalam upaya peningkatan efektivitas pelayanan. Masalah nyata yang masih sering terjadi pada proses pelayanan umum/public yaitu mengenai lambatnya aparatur pemerintah dalam memberikan pelayanan, prosedur pelayanan yang berbelit-belit, sarana prasarana pendukung pelayanan 
yang masih kurang dan masih banyak lagi. Peran pemerintah yang strategis, akan banyak ditopang oleh kemampuan aparatur pemerintah dalam melaksanakan tugas dan fungsinya. Salah satu tantangan besar yang dihadapi oleh pemerintah adalah kemampuan melaksanakan kegiatan secara efektif dan efisien, (Mulyadi, 2012).

Banyak penelitian yang dilakukan untuk mengetahui persepsi masyarakat terhadap pelayanan publik. Salahsatunya penelitian yang dilakukan oleh Heriyanto (2015), penelitian ini bertujuan untuk mengetahui persepsi masyarakat terhadap kualitas pelayanan publik pada bagian Administrasi Kesejahteraan Rakyat Pemerintah Kabupaten Gunungkidul, yang selama ini belum diketahui, menyangkut kesederhanaan, kejelasan, kepastian waktu penyelesaian, tanggungjawab pegawai, kemudahan akses, kelengkapan sarana dan prasarana, perilaku pegawai, serta kenyamanan. Hasil penelitian ini menunjukkan bahwa persepsi warga masyarakat pengguna pelayanan pada bagian Administrasi Kesejahteraan Rakyat Pemerintah Kabupaten Gunungkidul menyatakan penyelenggaraan pelayanan masih kurang memuaskan pada beberapa aspek. Beberapa aspek yang mempengaruhi kualitas pelayanan publik pada Bagian Administrasi Kesejahteraan Rakyat Pemerintah Kabupaten Gunungkidul, yaitu aspek kejelasan (kurang jelasnya syarat teknis dan admnistratif), aspek sarana dan prasarana yang masih kurang, aspek kemudahan akses (website yang masih kurang informative dan pembaruan), aspek keindahan (penataan ruang yang terkesan sempit) .

Peningkatan pelayanan umum setiap wilayah mempunyai strategi untuk melaksanakan pelayanan umum dengan baik dengan selalu meningkatkan kinerja perangkat desa. Salah satu desa yang selalu meningkatkan pelayanan umum kepada masyarakat adalah desa Bomo. Desa Bomo sendiri bertempat di kecamatan Blimbingsari Kabupaten Banyuwangi Jawa timur.

Pelayanan umum yang diselenggarakan oleh pemerintah desa bomo melibatkan seluruh aparat yang ada didesa. Pelayanan menjadi suatu hak masyarakat, yaitu hak atas pelayanan. Namun ternyata hak masyarakat atau perorangan untuk memperoleh pelayaan dari aparat pemerintah desa terasa belum dapat memenuhi harapan semua pihak, baik masyarakat itu sendiri maupun pemerintah. Masih banyak ditemui kelemahan-kelemahan yang dampaknya sering merugikan warga masyarakat yang menerima layanan tersebut. Maka dari itu pemerintah

Tujuan dari penelitian ini adalah Untuk mengetahui persepsi masyarakat tentang kinerja pemerintahan desa Bomo Blimbingsari Banyuwangi dalam memberikan pelayanan kepada warga masyarakat.

\section{METODE}

Jenis penelitian ini adalah kualitatif deskriftif, dengan pendekatan fenomenologis dengan subjek yaitu pemerintahan desa dan warga masyarakat Bomo Kecamatan Blimbingsari Banyuwangi. Pendekatan fenomenologi merupakan suatu pendekatan filsafat yang berpusat pada analisis terhadap gejala yang membanjiri kesadaran manusia (Hasbiansyah, 2005). Tujuan dengan pendekatan ini Untuk mengetahui persepsi masyarakat tentang kinerja pemerintahan desa Bomo Kecamatan Blimbingsari Banyuwangi dalam memberikan pelayanan kepada warga masyarakat desa secara sistematis dari suatu fakta secara faktual dan cermat.

Adapun teknik Pengumpulan Data yang digunakan peneliti yaitu teknik wawancara, teknik observasi, dan teknik dokumentasi. Teknik dokumentasi yaitu diperoleh dari interaksi bersama warga yang terlibat langsung dalam penelitian. Observasi yang dilakukan peneliti yaitu observasi partisipan dimana peneliti terlibat dan datang secara langsung ditengahtengah kegiatan subjek penelitian. Wawancara dilakukan secara langsung dimana peneliti berhadapan langsung dengan narasumber dan menggunakan teknik wawancara terstruktur.

Analisis data yang digunakan dalam penelitian ini menggunakan model Miles and Huberman yang mengemukakan bahwa aktivitas dalam analisis data kualitatif dilakukan secara interaktif dan berlangsung secara terus menerus sampai tuntas, sehingga datanya sudah jenuh. Aktivitas dalam analisis data, yaitu data reduction, data display, dan conclusion drawing/verification.

Pengecekan keabsahan data merupakan uji kepercayaan terhadap data dan bertujuan untuk menguji kebenaran data atau informasi yang diperoleh. Dalam penelitian kualitatif dapat dilakukan dengan cara triangulasi. Triangulasi dalam pengujian kredibilitas ini diartikan sebagai pengecekan data dari berbagai sumber dengan berbagai cara, dan berbagai waktu. (Sugiyono, 2017).

Teknik triangulasi dalam penelitian ini dilakukan dengan cara membandingkan data antara hasil wawancara dengan observasi,hasil observasi dengan dokumentasi, serta hasil dokumentasi dengan hasil wawancara.

\section{HASIL DAN PEMBAHASAN}

Wilayah desa Bomo secara geografis terletak pada dataran tinggi dan sebagian terletak di dataran rendah yang berjarak $\pm 10 \mathrm{Km}$ arah timur dari pusat kecamatan dan memiliki potensi yang cukup strategis dengan luas wilayah 569.666 Ha yang terbagi menjadi 3 Dusun, yakni: Dusun Kedunen, Dusun Jatisari, Dusun Krajan, dengan perbatasan wilayah sebagai berikut: 


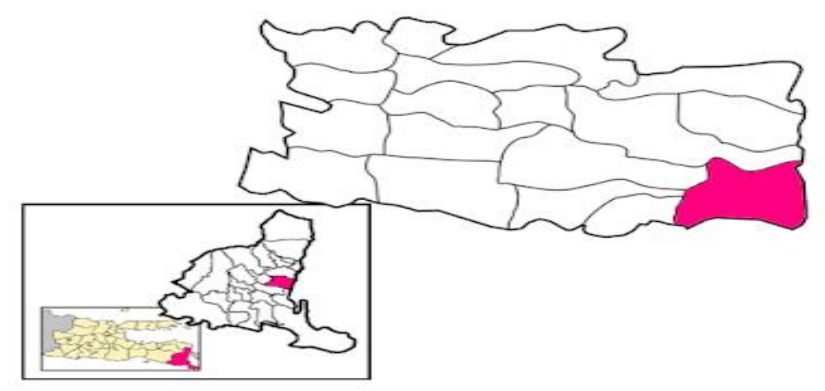

Gambar 1. Peta Wilayah Desa Bomo

\section{Utara : Berbatasan dengan Desa Watukebo Kecamatan Rogojampi}

Barat : Berbatasan dengan Desa Gintangan dan Karangrejo Kecamatan Rogojampi

Selatan : Berbatasan dengan Desa Kumendung Kecamatan

Timur : Berbatasan dengan Selat Bali

Sejarah Desa Bomo dimulai sebelum abad ke-18, yaitu suatu wilayah yang berbatasan antara Kecamatan Rogojampi dengan Kecamatan Muncar dan berdirilah desa yang diberi nama Bomo. Adapun asal mula Desa Bomo tersebut konon ceritanya adalah sebagai berikut. Pada zaman dahulu kala masih hutan belantara nama Bomo belum ada sedangkan penduduk yang menghuni wilayah tersebut masih sedikit sekali. Pada suatu saat datanglah 5 (lima) ekor kerbau (bahasa jawanya kebo limo) datang di wilayah tersebut dan mengamuk. Sedangkan untuk keselamatan orang-orang yang menghuni di daerah itu maka Kelima Kerbau tersebut harus dimusnahkan (dibunuh), dan pada saat itu dibukalah sayembara yang isinya : "Barang siapa yang bisa membunuh lima kerbau (kebo limo) tersebut, maka dialah yang berhak mempunyai Wilayah Desa tersebut".

Pada saat itu datanglah sekelompok orang dari wilayah selatan, dan mengikuti sayembara dan kemudian mereka berhasil membunuh lima Kerbau (limo kebo) tersebut, dan pada akhirnya pada waktu itu Desa tersebut diberi nama BOMO, diambil dari kata :

Bo : dari Kebo

Mo : dari Limo

Desa Bomo Kecamatan Blimbingsari memiliki jumlah penduduk sebanyak \pm 5.941 jiwa yang terdiri dari 2.795 jiwa penduduk laki-laki dan 2.755 jiwa penduduk perempuan. Potensi Desa Bomo sangat besar, baik potensi yang sudah dimanfaatkan oleh warga masyarakat, maupun yang belum dimanfaatkan secara maksimal. Potensi yang adadi desa Bomo baik sumber daya alam maupun sumber daya manusianya perlu terus digali dan dikembangkan untuk memwujudkan kemakmuran masyarakat secara umum.

Sebagian besar penduduk Desa Bomo berpendidikan SD/MI yaitu sebesar 2.775 orang atau $46,71 \%$, sedangkan sebanyak 1.664 orang atau $28,01 \%$ SMP/MTs, sebanyak 1.053 orang atau $17,72 \%$ SMA/MA, sebanyak 99 orang atau $1,67 \%$ berpendidikan
Perguruan Tinggi/ Akademi, dan sisanya yaitu sebanyak 350 orang atau 5,89\% tidak sekolah.

Penduduk desa Bomo Kecamatan Blimbingsari bermata pencaharian sebagai petani dan buruh tani sebanyak 2.950 orang $(59,00 \%)$, sebagai pegawai swasta sebanyak 270 orang (5,38\%), bekerja sebagai Pegawai Negeri Sipil sebanyak 13 orang $(0.26 \%)$, bekerja dibidang perdagangan sebanyak 14 orang $(0,28 \%)$, sebagai Pengrajin Batik sebanyak 9 orang $(0,18 \%)$, dan di bidang Nelayan sebanyak 498 orang $(9,91 \%)$.

Pelayanan desa adalah bentuk kegiatan dalam rangka pemenuhan kebutuhan dasar sesuai dengan hakhak dasar setiap warga Negara dan penduduk yang berkaitan dengan semua pelayanan. Pelayanan desa tidak terlepas dari keadaan kedisiplinan, kesopanan dan keramahan dalam memberikan pelayanan. Kedisiplinan berpengaruh dalam penyelesaian tugas yang diemban aparat desa. Bentuk-bentuk pelayanan administrasi yang ada di desa Bomo meliputi:

1. Surat Pengantar KTP

2. Surat Keterangan Kematian

3. Surat Pengantar SKCK

4. Surat Keterangan Kelahiran

5. Surat Keterangan Tidak Mampu (SKTM)

6. Surat Pengantar Kartu Keluarga

7. Surat Keterangan Penganti Nama

8. Surat Keterangan Pemasangan Listrik, Mampu Masyarakat Yang Kurang Mampu

9. Surat Keterangan Pindah Alamat Rumah dan Surat Keterangan Datang

10.Surat Keterangan Untuk Nikah (SKUN)

11. Surat Keterangan Mendirikan Banggunan

Kementrian Dalam Negeri RI menerbitkan Permendagri Nomor 2 tahun 2017 tentang Standar Pelayanan Minimal Desa pada 3 Januari 2017 dan diundangkan dalam Berita Negara Republik Indonesia tahun 2017 Nomor 156 pada 23 Januari 2017. Permendagri dengan 10 bab dan 29 Pasal ini mengatur tentang urusan pemerintahan desa dalam melayani kepentingan masyarakat desa. Sebagaimana wajah desa adalah wajah negara, Pelayanan Desa akhirnya memiliki Standar Pelayanan Desa Minimal yang bisa mempermudah masyarakat dalam berdesa.

Standar Pelayanan Minimal Desa yang disingkat menjadi SPM Desa memiliki maksud untuk mendekatkan, mempermudah, transparansi, dan efektif dalam memberikan pelayanan kepada masyarakat (Pasal 2). SPM Desa bertujuan untuk mendorong percepatan pelayanan kepada masyarakat, memberikan pelayanan kepada masyarakat sesuai dengan kewenangan desa, dan menjadi alat kontrol masyarakat kepada Pemerintah Desa (Pasal 3)

Standar Pelayanan Minimal Desa, SPM Desa ditetapkan dan diputuskan oleh Kepala Desa (Pasal 4). Ruang lingkup SPM Desa meliputi penyediaan dan penyebaran informasi pelayanan, penyediaan data dan informasi kependudukan dan pertanahan, pemberian 
surat keterangan, penyederhanaan pelayanan, dan pengaduan masyarakat (Pasal 5).

Dalam Pasal 11 ayat 4, Desa harus memiliki sarana dan prasarana Minimal sebagai berikut:

1. tempat/loket pendaftaran

2. tempat pemasukan berkas/dokumen

3. tempat pembayaran

4. tempat penyerahan dokumen

5. tempat pelayanan pengaduan

6. ruang tunggu, dan

7. perangkat pendukung lainnya

Kehidupan bermasyarakat tidak akan lepas dari persepsi masyarakat itu sendiri. Persepsi merupakan tanggapan atau penerimaan langsung dari seseorang. Menurut Jalaludin Rachmat (2011) persepsi merupakan pengalaman tentang obyek, peristiwa, atau hubunganhubungan yang diperoleh dengan menyimpulkan informasi dan menafsirkan pesan.

Dedi Mulyana (2005) menyebutkan bahwa secara garis besar persepsi manusia dibagi menjadi dua bagian, yaitu:

a) Persepsi terhadap obyek (lingkungan fisik); sifat-sifat luar, sedangkan persepsi terhadap orang menaggapi sifat-sifat luar dan dalam (perasaan, motif, harapan, dan sebagainya). Orang akan mempersepsi anda pada saat anda mempersepsi mereka. Dengan kata lain, persepsi terhadap manusia bersifat interaktif.

b) Persepsi terhadap manusia; melalui lambang-lambang fisik, sedangkan persepsi terhadap orang melalui lambang-lambang verbal dan nonverbal. Orang lebih aktif daripada kebanyakan obyek dan lebih sulit diramalkan.

Masyarakat desa Bomo berhak untuk menyampaikan pendapat tentang persepsi mereka terhadap kinerja pemerintahan desa terhadap pelayanan kepada masyarakat

Layanan kepada masyarakat di desa Bomo di buka mulai jam 08.00 pagi. Secara keseluruhan pelayanan yang diberikan pegawai desa kepada masyarakat dianggap sangat baik dan memuaskan masyarakat biarpun sebagian kecil masyarakat mengatakan sebaliknya. Hal terlihat dari sikap pegawai desa kepada masyarakat ramah dan dan sopan. Sehingga masyarakat desa Bomo sangat puas dengan pelayanan yang diberikan pegawai desa kepada masyarakat. Hal tersebut ditunjukan dari hasil penelitian ini

Peneliti telah melakukan wawancara kepada subjek penelitian yang berjumlah 26 orang. Berdasarkan pendapat dari 26 orang yang di wawancarai diperoleh data yaitu 76 persen masyarakat merasa puas dengan pelayanan yang diberikan pegawai desa Bomo kepada masyarakat karena mereka dianggap sangat baik, ramah, sopan, dan cepat dalam memberikan pelayanan. Sedangkan 24 persen kurang puas dengan pelayanan yang diberikan pegawai desa. Mayarakat yang tidak puas dengan pelayanan yang diberikan pegawai desa dikarenakan mereka harus bolak-balik dalam melengkapi berkas. Menurut pegawai desa masyarakat yang bolakbalik dalam melengkapi berkas dikarenakan mereka tidak memahami dan memperhatikan informasi yang telah diberikan.

Namun demikian komitmen daripada Pemerintahan desa dalam memberikan pelayanan kepada masyarakat sangat baik. Berbagai upaya telah dilakukan agar pegawai desa bisa professional dalam memberikan pelayanan kepada masyarakat yaitu salahsatunya mengirim pegawai desa untuk menghadiri seminar dan pelatihan-pelatihan untuk mengembangkan kemampuan pegawai dalam rangka meningkatan keprofesionalnya dalam memberikan kepuasan pelayanan kepada masyarakat.

Pelayanan dapat dikatakan memuaskan jika dapat memenuhi harapan penerima layanan. Adapun harapan pelayanan tersebut dapat diukur dengan melihat terpenuhi atau tidaknya pelayanan yang diberikan oleh perangkat desa kepada masyarakat dengan mengacu kepada sepuluh prinsip pelayanan umum yang diperjelas dalam Keputusan Menteri Pendayagunaan Aparatur Negara Nomor 63/KEP/M.PAN/7/2003, yang terdiri dari:

1. Kesederhanaan yaitu prosedur pelayanan publik tidak berbelit-belit, mudah dipahami dan mudah dilaksanakan

2. Kejelasan:

a. Persyaratan teknis dan administratif pelayanan publik.

b. Unit kerja/pejabat yang berwenang dan bertanggung jawab dalam kelurahan/ persoalan/ sengketa untuk pelayanan publik.

3. Kepastian waktu yaitu pelaksanaan pelayanan publik yang tepat waktu.

4. Akurasi, yaitu produk pelayanan publik diterima dengan benar, tepat, dah sah

5. Keamanan yaitu, proses dan produk pelayanan publik memberikan rasa aman dan kepastian hukum.

6. Tanggung jawab, pempinan penyelenggara pelayanan publik atau pejabat yang ditunjuk bertanggungjawab atas penyelenggaraan pelayanan dan penyelesai yang tepat

7. Kelengkapan sarana dan prasarana, yaitu tersedianya sarana dan prasarana kerja Peralatan kerja dan pendukung lainya yang memadai termasuk penyedian saranan.

8. Kemudahan akses, yaitu tempat dan lokasi serta sarana pelayanan

9. Kedisiplinan, yaitu pemberi pelayanan harus bersikap disiplin sopan dan santun dan memberikan pelayanan yang ikhlas

10. Kenyamanan yaitu lingkungan pelayanan harus tertib, teratur, disediakan ruang tunggu yang nyaman, bersih, rapi, lingkungan yang indah dan sehat serta dilengkapi dengan fasilitas pendukung seperti parker,toilet dan lain-lain. 


\section{SIMPULAN}

Persepsi masyarakat desa Bomo Kecamatan Blimbingsari Banyuwangi terhadap kinerja pemerintahan desa dalam memberikan pelayanan kepada warga masyarakat, 76 persen menganggap cukup baik dan memuaskan hal ini dibuktikan dengan pelayanan yang ramah, cepat, dan tepat waktu, sedangkan 24 persen menganggap kurang memuaskan dikarenakan mereka harus bolak-balik dalam melengkapi berkas

Rekomendasi yang dapat diberikan peneliti kepada pemerintahan desa agar dalam memberikan pelayanan kepada masyarakat dapat berjalan dengan baik dan maksimal yaitu dengan membuat dan mengembangkan pelayanan terpadu berbasis aplikasi IT desa, sehingga warga masyarakat lebih mudah mendapatkan akses informasi dan pelayanan.

\section{DAFTAR PUSTAKA}

Agus Dwiyanto (ed). (2010). Mewujudkan Good Governance Melalui Pelayanan Publik. Yogyakarta: Gajah Mada University Press

Deddy Mulyana. (2005). Ilmu Komunikasi: Suatu Pengantar. Bandung: PT. Remaja Rosdakarya

Heriyanto, (2015). Persepsi Masyarakat Terhadap Kualitas Pelayanan Publik Bagian Administrasi Kesejahteraan Rakyat Pemerintahan Kabupaten Gunungkidul. Thesis. Falkultas Ekonomi Universitas Negeri Yogyakarta

http://bomo.desa.id/web/detailnews/sejarahdesa. Diakses 9 Februari 2020

http://pemerintahdesabomo.blogspot.com/2015/10/profil -desa.html. Diakses 9 Februari 2020

Jalaludin Rakhmat, (2011). Psikologi Komunikasi. Bandung: PT. Remaja Rosdakarya.

Keputusan Menteri Pendayagunaan Aparatur Negara Nomor 63/KEP/M.PAN/7/2003 tentang Pedoman Umum Penyelenggaraaan Pelayanan Publik

Moch. Solekhan, M. (2014). Penyelenggaraan Pemerintahan Desa. Malang: Setara Press.

Permendagri Nomor 2 tahun 2017 Tentang Standar Pelayanan Minimal Desa

Ponijan (2012). Penilain Kinerja dan Komitmen Dalam Etika Pemerintahan. Universitas Satyagama.

Sugiyono. (2017). Metode Penelitian Kuantitatif, Kualitatif, dan R\&D. Bandung: Alfabeta

Solekhan, D. M. (2014). Penyelenggaraan Pemerintahan Desa Berbasis Partisipasi Masyarakat.Setara Press.

Suhardi. (2018). Persepsi Masyarakat Terhadap Kualitas Pelayanan Publik Pada Kantor Dinas Pendudukan Kota Batam. Benefita Vol 3(1) februari. Hal: 5363

Undang-Undang No. 6 Tahun 2014 Tentang Desa

Undang-Undang No. 25 tahun 2009 Tentang Pelayanan publik 